\title{
Methods of estimation of the pathogenicity of the fungus Phoma exigua var. exigua
}

\author{
JOANNA MARCINKOWSKA
}

Department of Phytopathology, Warsaw Agricultural University, Nowoursynowska 166, 02-766 Warszawa, Poland

〈Received: September 16. 1983〉

\begin{abstract}
During the period 1977-1981 33 isolates of Phoma exigua were recovered from diseased leaves, stems, root crowns and seeds of soybean cultivated in different localities of Poland. None of the obtained isolates caused disease symptoms on soybean and other plant species when they were inoculated by spraying with conidial suspension. Infection developed only on wounded plants after inoculation. Phoma exigua occurring on soybean in Poland is not a specialized pathogen of this plant, but a plurivorous weak or waund parasite which attacks all kinds of plants and so is $P$. exigua var. exigua. Among seven of the applied inoculation methods the best one seems to be the laboratory one, in Petri plates, with culture discs exposed on the seedling hypocotyl. Other methods varied in precision and were more time-consuming.
\end{abstract}

\section{INTRODUCTION}

On soybean plants (Glycine $\max \langle\mathrm{L}$. $\rangle$ Merill) cultivated in Poland $\langle\mathrm{M}$ a $\mathrm{r}$ c i n k o w s k a et al., 1982〉 and the USSR $\langle\mathrm{B}$ o n d a r c e v a - M o n t everde and Vas i le v s ki i, 1940〉, West Germany $\langle\mathrm{F} \mathrm{r}$ a n d s e n, 1953 >, Czechoslovakia $\langle\mathrm{O} \mathrm{n} \mathrm{d} \mathrm{r} \mathrm{e} \mathrm{j,} \mathrm{1976 \rangle} \mathrm{and} \mathrm{Hungary}\langle\mathrm{T}$ ò $\mathrm{t} \mathrm{h}$ and $\mathrm{K}$ öv i c s, 1978> spots on leaves and pods as well as blight on seedlings and"shoots of soybean were observed.

The cause of these diseases was described as Ascochyta sojaecola $\angle \mathrm{A} \mathrm{b} \mathrm{r}$ am o v, 1931 $\rangle$, A. sojae $\langle\mathrm{S}$ a w a d a, 1959 $\rangle$, A. phaseolorum $\langle\mathrm{C} \mathrm{r}$ o s s a n, 1953; M e l n i k; 1977〉 and lately as Phoma exigua $\langle\mathrm{O} \mathrm{n} \mathrm{d} \mathrm{r} \mathrm{e} \mathrm{j,} \mathrm{1976;}$ M a r c in k ow s k a, 1983 $\rangle$.

Some investigators $\langle\mathrm{A} \mathrm{b} \mathrm{r} \mathrm{a} \mathrm{m} \mathrm{o} \mathrm{v,} \mathrm{1931;} \mathrm{F} \mathrm{r} \mathrm{a} \mathrm{n} \mathrm{d} \mathrm{s} \mathrm{e} \mathrm{n}, 1953\rangle$ considered this fungus as a pathogen specific to soybean, others believed that this species may attack various plants $\langle\mathrm{B}$ o $\mathrm{nd} \mathrm{a} \mathrm{ce} v \mathrm{a}-\mathrm{M}$ o $\mathrm{n} \mathrm{te} \mathrm{ver} \mathrm{de}$ and $\mathrm{V}$ as i l e v s kii, 1940; C r o s s a n, 1953; O n d r e j, 1976 $\rangle$. The question 
arose whether the cause of leaf spot and blight on seedlings and soybean shoots in Poland is the polyphagous fungus of weak pathogenicity for soybean in Poland or whether it is a fungus infecting solely soybean. To find an answer to these questions the pathogenicity of a number of isolates obtained from the infected parts of soybean plants was tested by various inoculation methods in respect to soybean and other plant species.

\section{MATERIAL AND METHODS}

Fungus isolates for pathogenicity tests represented various morphological types of cultures. They were obtained in the period 1977-1981 from various infected parts of soybean plants cultivated throughout Poland $\langle\mathrm{M}$ a $\mathrm{r} \mathrm{c}$ i $\mathrm{n}$ $\mathrm{k}$ o w s k a, 1983 $\rangle$. In the experiments 16 isolates from leaves, 11 from shoots, 2 from hypocotyls and one each from cotyledons, root neck and seed were studied. The fungus was kept on potato dextrose agar, PDA, at $5^{\circ} \mathrm{C}$. Soybean plants of the variety 'Ajma' were infected. Usually all combinations included four replications. As replication served plants in one pot $\langle 5-6\rangle$. During the experiments in the glasshouse temperature was maintained at $18-25^{\circ} \mathrm{C}$ and in the laboratory at 20 $22^{\circ} \mathrm{C}$ as optimal temperature for the fungus development. The inoculated plants were covered for $48 \mathrm{~h}$ with plastic chamber to ensure 100 per cent relative air humidity. Later moisture was maintained within $65-85$ per cent.

Germination capacity of the conidia was checked directly on sprayed leaves $\langle\mathrm{M}$ a r c i n k o w s k a, 1977〉 and in hanging drops on concave slides parallelly with the experiment. The inoculum for plant and seed infection was prepared from 8-and 12-day culture on PDA. The concentration of conidia was 2 million spores in $1 \mathrm{ml}$ of aqueous suspension. In the control combination the plants or seeds were treated with water, pure medium or used media were free from the fungus.

\section{METHODS OF SOYBEAN PLANT INOCULÁTION}

Method 1. Spraying of intact plants with conidial suspension

The plants were inoculated at the phase of 3 rd pair of trifoliate leaves with conidial suspension of all the 33 fungus isolates. For each plant $1 \mathrm{ml}$ of inoculum was used. The experiment was replicated four times.

\section{Method 2. Rubbing soybean leaves with conidial suspension}

Soybean leaves were powdered with carborundum at the phase of three trifoliate leaves and the inoculum was rubbed in with a cotton swab. The pathogenicity of 12 isolates obtained from soybean leaves was tested. Soybean 
shoots were inoculated in the same way at the phase of the first pod. The shoots were inoculated with 11 cultures isolated from shoots.

The methods of spraying and rubbing the inoculum into the plants were used to investigate the influence of 100 per cent relative air humidity on infection of the plants and the further development of the disease. Cotyledones and leaves of seedlings in the phase of cotyledones and developing first leaves were inoculated with isolates from a leaf $\langle\mathrm{L} 6\rangle$, hypocotyl $\langle\mathrm{SK} 6\rangle$, and shoots $\langle\mathrm{P} 9\rangle$. One half of plants inoculated by both methods was kept under foil chambers as usual for two days after inoculation, and a second one for six days to ensure 100 per cent relative air moisture.

Method 3. Drop-wise application of homogenate of culture on wounded shoot

The inoculum consisted of an aqueous suspension of conidia and mycelium from homogenized cultures with a part of the medium. A few drops of homogenate were placed on the lesion arising by pulling off three leaves of the central part of the plant at the phase of the first pod.

\section{Method 4. Placement of culture discs on cotyledones}

Discs of PDA cultures were placed on cotyledones of soybean seedlings. Then the mycelial disc was punctured with a sterile needle, wounding at the same time the cotyledone in one half of the inoculated plants. For a better development of the disease a 100 per cent relative air moisture was maintained for six days to the plants after inoculation.

\section{METHODS OF INOCULATION OF SOYBEAN SEEDS}

Seeds of the variety 'Ajma' healthy in appearance were disinfected after washing in water with a detergent, in ethyl alcohol $\langle 96 \%\rangle$ and Perhydrol $\langle 15 \%\rangle$ for $15 \mathrm{~s}$. In each experiment 10 disinfected seeds were placed in a pot $\langle$ replication〉.

Method 5. Placement of seeds on infected substrate

Cultures of 13 fungus isolates from PDA were placed in pots filled to $3 / 4$ of height with soil and peat. On each culture seeds were sown and covered with soil.

Method 6. Inoculation by contact in substrate with infected seeds $\langle\mathrm{D}$ u n 1 e a v y, 1958〉

The seeds were seeded in pots at a depth of $2 \mathrm{~cm}$ and lightly covered with soil $\langle 0.5 \mathrm{~cm}\rangle$. Over them were placed soybean seeds overgrown with mycelium of each of 12 isolates. The seeds serving as inoculum were covered with soil. 
Method 7. Soaking of seeds in spore suspension

$\langle\mathrm{T}$ ò $\mathrm{h}$ and $\mathrm{K} \ddot{\mathrm{o}} \mathrm{vi} \mathrm{cs}, 1978\rangle$

Sterile seeds.swollen after $48 \mathrm{~h}$ of soaking in dishes with moist filter paper were soaked for $30 \mathrm{~min}$ in a suspension of conidia from 12 isolates and then seeded in pots.

\section{INOCULATION OF VARIOUS PLANT SPECIES}

Various plant species were inoculated with isolates obtained from soybean by methods 1,4 and 7. The experiments were to indicate the pathogenicity of the fungi isolated from soybean towards other plant species.

Spraying of intact plants with conidial suspension $\langle\operatorname{method} 1\rangle$

Asters 〈Callistephus chinensis Nees $\rangle$, field bean 〈Vicia faba subsp. minor Harz $\rangle$, bean $\langle$ Phaseolus vulgaris L. $\rangle$, pea $\langle$ Pisum sativum L. $\rangle$, cabbage $\langle$ Brassica oleracea var. capitata alba $\mathrm{L}$. $\rangle$, maize $\langle$ Zea mays L. $\rangle$, yellow lupin $\langle$ Lupinus luteus L. $\rangle$, cucumber $\langle$ Cucumis sativus L. $\rangle$,"parsley $\langle$ Petroselinum sativum Hoffm. $\rangle$, tomato $\langle$ Lycopersicon esculentum Mill. $\rangle$, radish $\langle$ Raphanus sativus var. sativus Mansf. $\rangle$, bird's-foot $\langle$ Ornithopus sativus L. $\rangle$, vetch $\langle$ Vicia sativa L. $\rangle$ and soybean in the phase of 3-5 leaves in dependence on the plant species were three time inoculated with 33 fungus isolates.

\section{Placement of discs of cultures $\langle$ method 4〉}

In a glasshouse experiment discs of isolate cultures from leaves $\langle$ L6 $\rangle$ were placed on cotyledones or the two lowest situated leaves of field bean, bean, pea, lupin, cucumber, tomato, radish and soybean. Further procedure was the same as with soybean in method 4 .

Laboratory experiments were performed in plates $12 \mathrm{~cm}$ in diametre. Into these plates lined with moist filter paper six healthy seedlings were placed with 2-3 cm sprouts. Discs of cultures were placed on injured hypocotyls of pea, lupin, cucumber, radish and soybean seedlings. For inoculation isolates representing various morphological types of cultures were used, that is L14 from leaves and SK6 from soybean root neck and PD 79/118 from chicory roots. All in five replications 〈plates $\rangle$.

Soaking of seeds in spore suspension $\langle\operatorname{method} 7\rangle$.

The same plant species were inoculated as in the previous glasshouse experiment with a conidial suspension prepared from naturally infected shoots. The procedure was the same as with soybean in method 7 . 


\section{RESULTS}

\section{RESULTS CONCERNING SOYBEAN PLANTS AND SEED INOCULATION}

Method 1. After spraying of intact soybean plants with a spore suspension no disease symptoms were noted on any of the plants inoculated with the 33 isolates obtained from various soybean parts.

Method 2. On the leaves of soybean plants infected with 12 isolates from leaves and lesioned during inoculation by rubbing, brownish grey minute $\langle 2-3$ $\mathrm{mm}\rangle$ or larger $\langle 5-7 \mathrm{~mm}\rangle$ diffuse spots appeared. The intensity of disease symptoms was estimated according to the number and size of the spots. It was highest with four isolates $\langle\mathrm{L} 14, \mathrm{~L} 18, \mathrm{~L} 22, \mathrm{~L} 24\rangle$ and lowest for the isolate L10. The remaining seven isolates gave a moderate leaf infection, the leaf blades were destroyed in 20-30 per cent. On the two control plants spots were observed caused by mechanical damage to the tissue by rubbing. Prolongation of exposure time of the plants after inoculation to 100 per cent relative air moisture did not influence the disease symptoms on plants not subjected to lesions. Among the plants wounded with carborundum the number of infected plants was similar apart from incubation time under 100 per cent relative air humidity. For the isolate L6 the number of infected plants among the 24 inoculated was 22 and 23, for P9 - 19 and 20, for SK6 19 and 19, respectively. On the cotyledones and first leaves of plants incubated for 2 days there appeared, however, minute spots $\langle$ ca. $2 \mathrm{~mm}$, whereas on the cotyledones and first leaves of plants kept under the moist chamber for 6 days the spots were somewhat larger <ca. $3-4 \mathrm{~mm}$ in diametre $>$ diffuse, with poorly delineated edges. All the infected plants had but few spots.

Methods 2 and 3. On the shoots of soybean plants damaged during inoculation by rubbing with a swab imbibed with inoculum brownish necrotic spots were visible on the shoots of most $\langle 83-100 \%\rangle$ of the inoculated plants

$$
\text { Table } 1
$$

Comparison of infection of soybean shoots inoculated. by various methods

\begin{tabular}{lcc}
\hline & $\begin{array}{c}\text { No. of plants with symptoms } \\
\text { on shoots in relation to no. of plants } \\
\text { inoculated by the method }\end{array}$ \\
\cline { 2 - 3 } $\begin{array}{l}\text { Results for } 11 \\
\text { fungus isolates }\end{array}$ & $\begin{array}{c}\text { of rubbing in } \\
\text { conidial } \\
\text { suspension }\end{array}$ & $\begin{array}{c}\text { application of } \\
\text { inoculum dropwise } \\
\text { on lesion }\end{array}$ \\
\hline Mean & & \\
Minimal & $21 / 24$ & $15 / 24$ \\
Maximal & $20 / 24$ & $7 / 24$ \\
& $24 / 24$ & $23 / 24$ \\
\hline
\end{tabular}


Table 2

Influence of inoculation of cotyledones with discs of Phoma exigua var. exigua culture on infection of soybean seedlings

\begin{tabular}{|c|c|c|c|c|}
\hline \multirow[t]{2}{*}{$\begin{array}{l}\text { Fungal } \\
\text { isolate }\end{array}$} & \multicolumn{2}{|c|}{$\begin{array}{l}\text { No. of dead seedlings } \\
\text { as compared with no. } \\
\text { of inoculated plants }\end{array}$} & \multicolumn{2}{|c|}{$\begin{array}{l}\text { No. of infected shoots } \\
\text { of seedlings as compared } \\
\text { with no. of inoculated } \\
\text { plants }\end{array}$} \\
\hline & $\begin{array}{l}\text { inoculation } \\
\text { intact }\end{array}$ & $\begin{array}{l}\text { cotyledones } \\
\text { injured }\end{array}$ & $\begin{array}{c}\text { inoculation } \\
\text { intact }\end{array}$ & $\begin{array}{l}\text { cotyledones } \\
\text { injured }\end{array}$ \\
\hline L2 & $14 / 28$ & $17 / 28$ & $1 / 28$ & $1 / 28$ \\
\hline L3 & $12 / 25$ & $7 / 28$ & $1 / 28$ & 0 \\
\hline L6 & $19 / 24$ & $13 / 28$ & $5 / 24$ & 0 \\
\hline P8 & $2 / 28$ & $16 / 28$ & $1 / 28$ & $4 / 28$ \\
\hline P9 & $4 / 24$ & $4 / 24$ & $7 / 24$ & $6 / 24$ \\
\hline K5 & $14 / 28$ & $12 / 24$ & $1 / 28$ & 0 \\
\hline SK6 & $16 / 28$ & $18 / 28$ & 0 & $2 / 28$ \\
\hline
\end{tabular}

T a ble 3

Influence of various methods of inoculation of soybean seeds on seed germination and infection of seedlings

\begin{tabular}{|c|c|c|c|c|c|c|}
\hline \multirow{3}{*}{$\begin{array}{l}\text { Fungal } \\
\text { isolate }\end{array}$} & \multicolumn{6}{|c|}{ Methods of seed inoculation } \\
\hline & \multicolumn{2}{|c|}{$\begin{array}{c}\text { Inoculation of } \\
\text { culture of fungus } \\
\end{array}$} & \multicolumn{2}{|c|}{$\begin{array}{l}\text { substrate with: } \\
\text { infected seeds }\end{array}$} & \multicolumn{2}{|c|}{$\begin{array}{l}\text { Soaking of seeds in } \\
\text { conidial suspension }\end{array}$} \\
\hline & $\begin{array}{l}\text { no. of } \\
\text { sprouting } \\
\text { seedlings }\end{array}$ & $\begin{array}{c}\text { no. of } \\
\text { diseased } \\
\text { seedlings }\end{array}$ & $\begin{array}{l}\text { no. of } \\
\text { sprouting } \\
\text { seedlings }\end{array}$ & $\begin{array}{c}\text { no. of } \\
\text { diseased } \\
\text { seedlings }\end{array}$ & $\begin{array}{l}\text { no. of } \\
\text { sprouting } \\
\text { seedlings }\end{array}$ & $\begin{array}{c}\text { no. of } \\
\text { diseased } \\
\text { seedlings }\end{array}$ \\
\hline $\mathbf{L} 2$ & 13 & 0 & 20 & 0 & 22 & 2 \\
\hline $\mathbf{L 3}$ & 19 & 0 & 19 & $\mathbf{0}$ & 12 & 2 \\
\hline L6 & 17 & 1 & 16 & $\mathbf{0}$ & 20 & 3 \\
\hline L14 & 14 & 1 & 21 & $\mathbf{0}$ & 28 & $\mathbf{0}$ \\
\hline L21 & 17 & 2 & 20 & $\mathbf{0}$ & 24 & 4 \\
\hline L24 & 17 & 1 & 18 & 1 & 21 & 2 \\
\hline $\mathbf{P 8}$ & 17 & $\mathbf{0}$ & 22 & $\mathbf{0}$ & 24 & 2 \\
\hline P9 & 16 & $\mathbf{0}$ & 22 & $\mathbf{0}$ & 20 & 4 \\
\hline P23 & 21 & $\mathbf{0}$ & 23 & $\mathbf{0}$ & 23 & 4 \\
\hline K5 & 17 & 0 & 20 & 1 & 24 & 2 \\
\hline SK6 & 13 & 0 & 19 & 2 & 20 & 3 \\
\hline $\mathrm{N} 43$ & 16 & 1 & & & & \\
\hline PD79/118 & 18 & $\mathbf{0}$ & 19 & 0 & 19 & 0 \\
\hline $\begin{array}{l}\text { Control } \\
\text { Sample }\end{array}$ & 20 & $\mathbf{0}$ & 24 & 0 & 24 & 0 \\
\hline
\end{tabular}




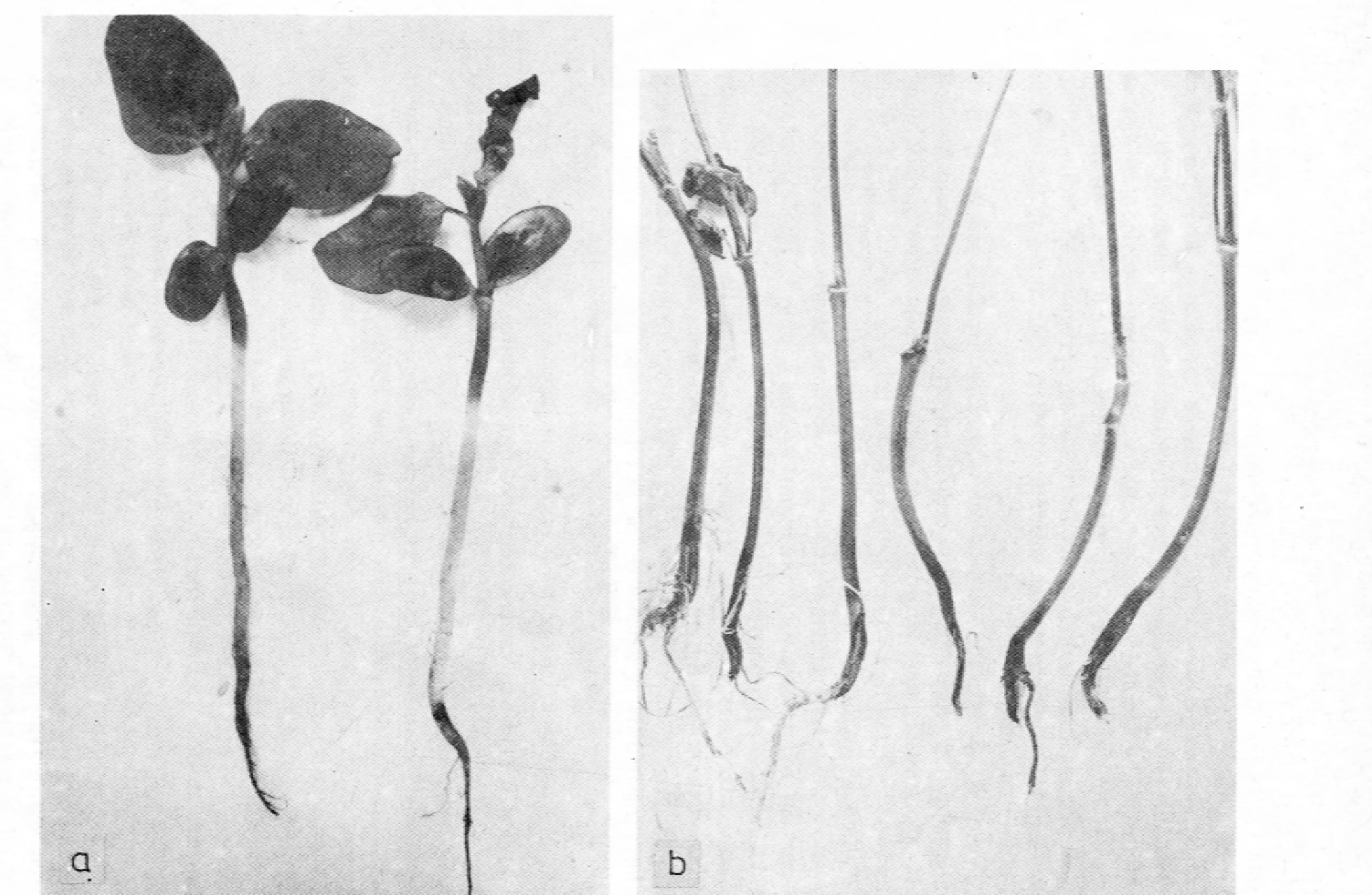


$\langle$ Table 1 $\rangle$. As the result of shoot infection owing to application of inoculum dropwise at the site where the leaf was torn off there formed along the shoots on the surface brownish streaks. Disease symptoms appeared in 29-95 per cent of plants $\langle$ Table 1$\rangle$. Sometimes only one or two streaks were observed.

Method 4. On some injured or unaffected soybean cotyledones disease symptoms appeared $\langle$ Table 2$\rangle$. In part of the plants the fungus grew from the cotyledones on to the shoot. In the course of the experiment some seedlings died, others showed symptoms on the shoot, and others after shedding the infected leaves developed further as healthy plants.

Method 5. Most of the tested isolates decreased by 5-35 per cent soybean seed germination when the latter were placed on fungus cultures in the soil $\langle$ Table 3$\rangle$. Only single seedlings, however, exhibited symptoms of surface blight of the root neck caused by five of the 13 tested isolates $\langle$ Fig. 1$\rangle$.

Method 6. As the result of inoculation by contact of healthy seed in the substrate with seed overgrown with mycelium soybean germination decreased by 5-34 per cent in the case of all the 12 fungus isolates $\langle$ Table 3$\rangle$. Blight of the root neck of the seedlings occurred only sporadically.

Method 7. Seeds soaked in a suspension of conidia of most isolates germinated worse than the control ones soaked in water $\langle$ Table 3$\rangle$. Blight of the root neck developed only on the surface of seedlings. It was noted on several seedlings infected by 10 isolates of the 12 ones tested.

\section{RESULTS CONCERNING INOCULATION OF VARIOUS PLANT SPECIES}

Method 1. Intact aster, field bean, bean, pea, cabbage, maize, yellow lupin, cucumber, parsley, tomato, radish, bird's-foot, vetch and soybean plants sprayed with a suspension of 33 fungal isolates did not show any disease symptoms.

Method 4. Seedlings of field bean, bean, pea, lupin, cucumber, tomato, radish and soybean inoculated with discs of culture and left for six days under 100 per cent relative air moisture showed symptoms both on injured and intact cotyledones and leaves $\langle$ Table 4$\rangle$. Nine days after inoculation some diseased seedlings died, others shed the infected cotyledones and developed further health, and in still others the fungus caused disease symptoms on the shoots, cotyledones and leaves. On many plants of field bean and bean and some soybean plants brown streaks were visible on the shoots, beginning with the node at which the dead leaf or cotyledone was situated. On radish and cucumber small necrotic spots appeared on the leaves at the site where the disc of fungus culture was placed. Similar spots were sporadically observed on pea plants.

In the laboratory experiments, where by means of discs of fungus culture the effectiveness of hypocotyl inoculation of seedlings of several plant species was

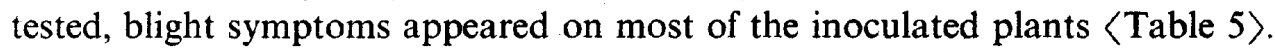
The isolate PD79/118 from chicory Cichorium intybus L. produced usually 
Ta ble 4

Influence of leaf inoculation with discs of Phoma exigua var. exigua culture on seedling infection of some plant species. under glasshouse conditions

\begin{tabular}{|c|c|c|c|c|}
\hline \multirow{2}{*}{$\begin{array}{l}\text { Inoculated } \\
\text { plant }\end{array}$} & \multicolumn{2}{|c|}{$\begin{array}{l}\text { No. of dead seedlings } \\
\text { in relation to no. of } \\
\text { inoculated plants }\end{array}$} & \multicolumn{2}{|c|}{$\begin{array}{l}\text { No. of infected leaves } \\
\text { and shoots of seedlings } \\
\text { in relation to no. } \\
\text { inoculated plants }\end{array}$} \\
\hline & \multicolumn{2}{|c|}{ Leaf inoculation } & \multicolumn{2}{|c|}{ Leaf inoculation } \\
\hline Cucumis sativus & $11 / 28$ & $6 / 30$ & $3 / 28$ & $4 / 30$ \\
\hline Glycinea max & $14 / 30$ & $6 / 28$ & $1 / 30$ & $1 / 28$ \\
\hline Lupinus luteus & $28 / 30$ & $24 / 28$ & 0 & $3 / 28$ \\
\hline Lycopersicon esculentum & $1 / 30$ & $4 / 28$ & $\mathbf{0}$ & $2 / 28$ \\
\hline Phaseolus vulgaris & $2 / 32$ & $6 / 28$ & $28 / 32$ & $19 / 28$ \\
\hline Pisum sativum & $\mathbf{0}$ & $\mathbf{1} / \mathbf{3 0}$ & 0 & $4 / 30$ \\
\hline $\begin{array}{l}\text { Raphanus sativus } \\
\text { var. sativus }\end{array}$ & $\mathbf{0}$ & 0 & $11 / 30$ & $20 / 28$ \\
\hline $\begin{array}{l}\text { Vicia faba } \\
\text { subsp. minor }\end{array}$ & $2 / 32$ & $1 / 30$ & $26 / 32$ & $25 / 30$ \\
\hline
\end{tabular}

Table 5

Effectiveness of inoculation of several plant species with three isolates of Phoma exigua var. exigua in laboratory experiment

\begin{tabular}{lccc}
\hline $\begin{array}{c}\text { Inoculated } \\
\text { plant }\end{array}$ & $\begin{array}{c}\text { No. of diseased seedlings in relation } \\
\text { of no. of seedlings inoculated with } \\
\text { the isolates: }\end{array}$ \\
\cline { 2 - 4 } & PD 79/118 & L 14 & SK 6 \\
\hline Cucumis sativus & $30 / 30$ & $30 / 30$ & $28 / 30$ \\
Glycinea max & $18 / 30$ & $30 / 30$ & $30 / 30$ \\
Lupinus luteus & $16 / 30$ & $29 / 30$ & $28 / 30$ \\
Pisum sativum & $18 / 30$ & $26 / 30$ & $24 / 30$ \\
Raphanus sativus & $18 / 30$ & $30 / 30$ & $30 / 30$ \\
$\quad$ var. sativus & & & \\
\hline
\end{tabular}

surface blight on the root necks of pea, lupin, cucumber, radish and soybean. Isolate of SK6 from the root neck and L14 from soybean leaves in most cases caused blight of deeper lying tissues of the root neck in the tested plant species. Sometimes blight developed around the root neck. Usually the seedling was infected only on the segment equal in diametre to the disc of culture applied, but sometimes browning of tissues spread on a longer segment causing even dying back of the radicle $\langle$ Fig. 2$\rangle$. 

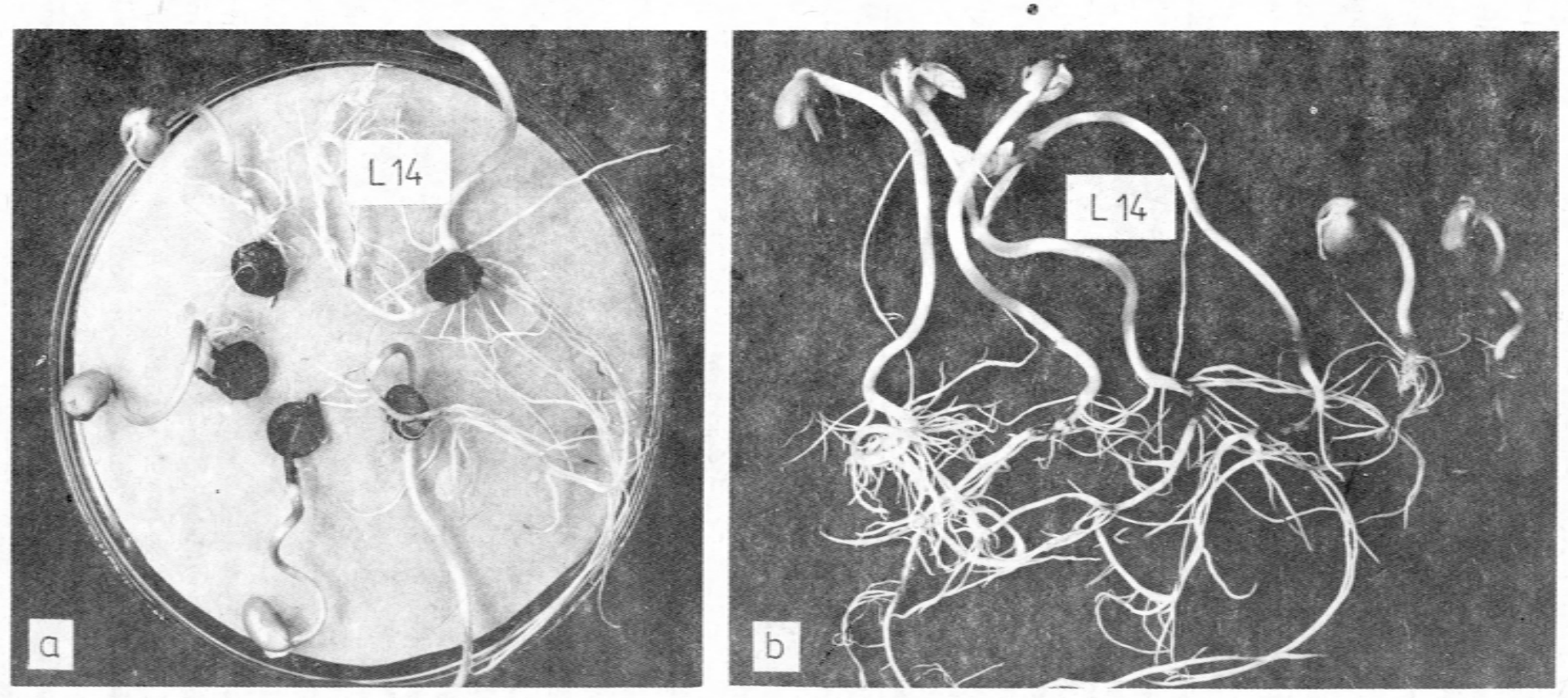

Fig. 2. Blight of root neck of soybean seedlings in laboratory experiment: a - necrosis of tissues at site of placement of discs of cultures and in their vicinity, b - symptoms on plants after removal of discs of fungal culture, plant on left healthy 

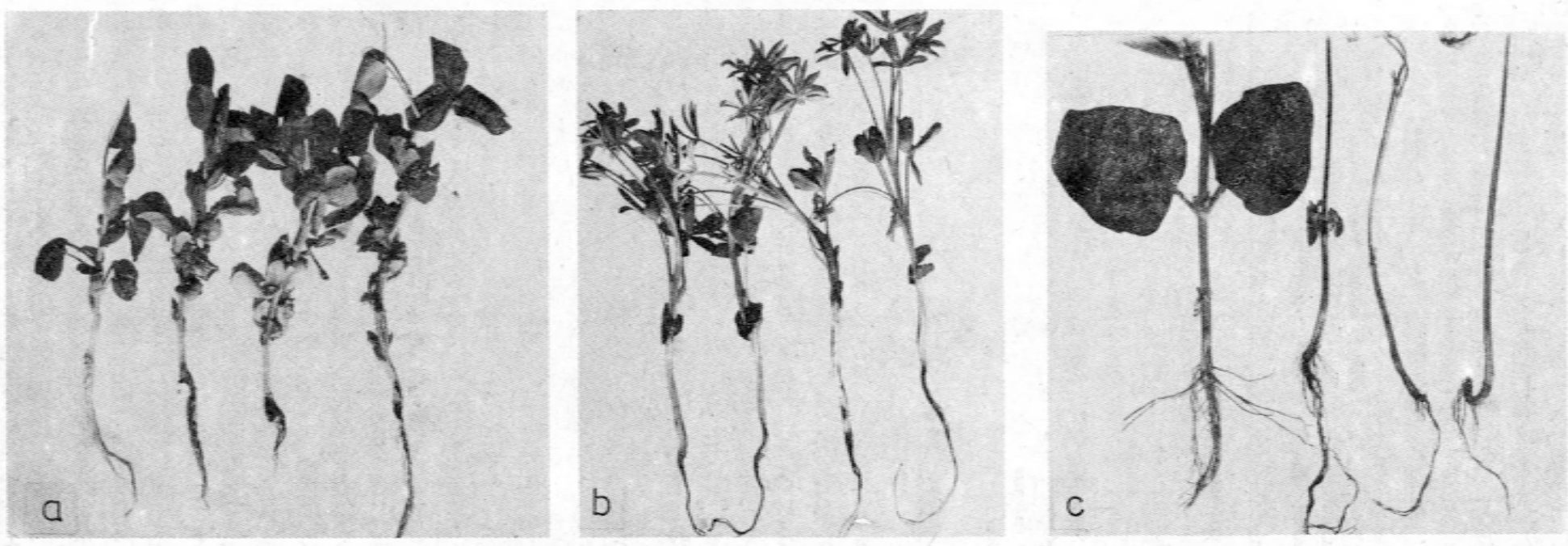

Fig. 3. Blight of root neck of seedlings of the following plants: a - pea, b - yellow lupin, $c-$ soybean. Plant on left healthy 
Table 6

Effectiveness of inoculation of several plant species by the method of soaking seeds in a conidial suspension from the fungus Phoma. exigua var. exigua

\begin{tabular}{|c|c|c|c|}
\hline \multirow{2}{*}{$\begin{array}{l}\text { Inoculated } \\
\text { plant }\end{array}$} & \multicolumn{2}{|c|}{$\begin{array}{l}\text { No. of spouting seedlings } \\
\text { after soaking of seeds in: }\end{array}$} & \multirow{2}{*}{$\begin{array}{l}\text { No. of } \\
\text { diseased } \\
\text { seedlings }\end{array}$} \\
\hline & water & inoculum & \\
\hline Cucumis sativus & 37 & 19 & 1 \\
\hline Glycinea max & 30 & 25 & 3 \\
\hline $\begin{array}{l}\text { Lupinus luteus } \\
\text { Lycopersicon escu. }\end{array}$ & 45 & 39 & 4 \\
\hline lentum & 35 & 30 & 0 \\
\hline Phaseolus vulgaris & 36 & 24 & 4 \\
\hline Pisum sativum & 46 & 38 & 5 \\
\hline $\begin{array}{c}\text { Raphanus sativus } \\
\text { var. sativus }\end{array}$ & 39 & 41 & 2 \\
\hline $\begin{array}{l}\text { Vicia faba } \\
\text { subsp. minor }\end{array}$ & 30 & 37 & 6 \\
\hline
\end{tabular}

Method 7. Seeds of cucumber, lupin, tomato, bean, pea and soybean soaked in a conidial suspension germinated worse than those soaked in water $\langle$ Table 6 $\mathbf{}$. The germination capacity of field bean and radish, however, was not depressed after soaking in the inoculum. Diseased seedlings grew from the seeds of most plants with the exception of tomato, soaked in conidial suspension $\langle$ Fig. 3$\rangle$. The number of seedlings with symptoms of blight was small, barely 5-17 per cent.

\section{DISCUSSION}

Inoculation experiments demonstrated that the fungus tested in Poland is a weak pathogen since it infected only injured or weak soybean plants and those of . other species, this indicating its polyphagous properties. These results additionally confirmed the correct conclusion, advanced on the basis of observation of the morphology and development of the cultures, that the tested fungus is the species Phoma exigua Desm. var. exigua 〈M a r c in k o w s k a, 1983〉. B ondarceva-M onteverde and Vasilevskii $\langle 1940\rangle$ in the USSR while studying the fungus obtained from A b r a m o v $\langle 1931\rangle$ indicated on its low pathogenicity for the soybean and other plants of the Leguminosae family. It is, thus, not a pathogen specific for soybean, as believed by $\mathrm{A} \mathrm{b} \mathrm{ra} \mathrm{m}$ o $\mathrm{w}\langle 1931\rangle$ when he described this fungus as a new species of Ascochyta sojaecola. The lack of specialization of the isolates from the genus Ascochyta obtained from soybean and other plants is also reported by C r o s s a $n\langle 1953\rangle$ from the USA, and O n d r e y $\langle 1976\rangle$ from the Czechoslovak Socialist Republic for Phoma exigua. In West Germany 
F r a n d s e n $\langle 1953$ > observed strong infection of soybean and bean by Ascochyta sojaecola in inoculation experiments. The infection of these two plant species may have indicated a lack of specialization, but the positive results of inoculation of healthy plants may be evidence of the high pathogenicity of the fungus. It is possibie that $\mathrm{Fr}$ a $\mathrm{n} \mathrm{d} \mathrm{se} \mathrm{n}\langle 1953\rangle$ isolated a fungus of high pathogenicity towards the tested plants since it is known $\langle\mathrm{B}$ o e $\mathrm{r}$ e $\mathrm{m}$ a et al., $1981\rangle$ in the German Federal Republic that morphologically similar species of Phoma exigua var. exigua and P. exigua var. diversispora have been noted on bean plants. The latter fungus exhibited a strong pathogenicity towards beans. On the other hand, P. exigua var. exigua appeared usually at the end of the bean vegetation season $\langle\mathrm{B}$ o e $\mathrm{r}$ e $\mathrm{m}$ a et al., 1981 $\rangle$. In Poland the latter fungus has been observed on soybean with a greater intensity aslo on ripening plants as well as on weakened yellowing once at the stage of full vegetation and also around necroses produced by other fungi $\langle$ Fig. 4$\rangle\langle\mathrm{M}$ a r c i n k o w s k a et al, $1982\rangle$.
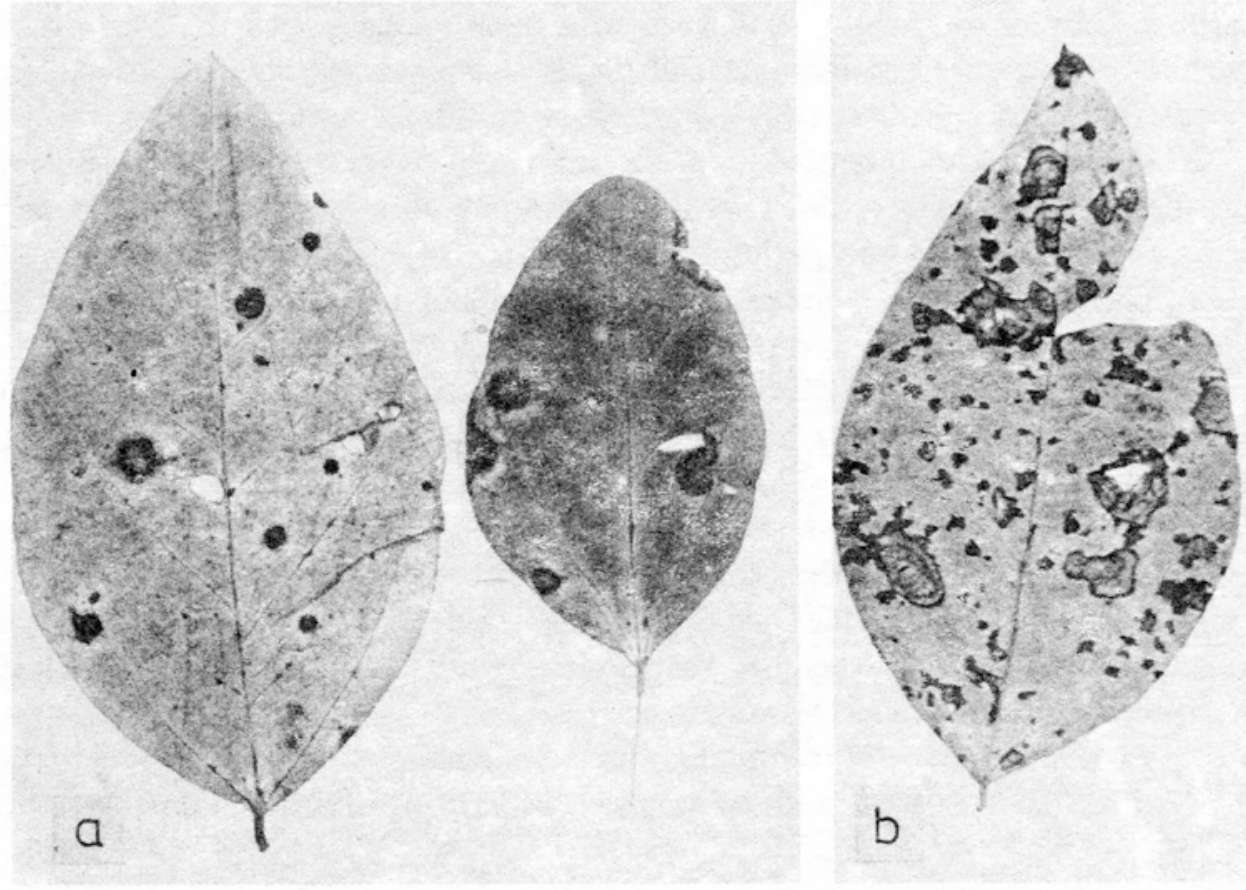

Fig. 4. Spots on soybean leaves from naturally infected plants: a - spots on leaves caused by fungus Phoma exigua var. exigua, b - on tissue infected by Peronospora manshurica, the fungus Phoma exigua var. exigua develops causing spread of necrotic spots on the leaves

In the case of each of the seed inoculation methods applied a depression of germination capacity of soybean seeds was observed. Most numerous seedlings were infected as the result of soaking in a suspension of conidia. This method was 
considered as the best in agreement with the opinion of the authors $\langle\mathrm{T}$ ò $\mathrm{t} h$ and $\mathrm{K}$ ö v i c s, 1978>, therefore, it was applied for inoculation of seeds of various plant species. Among the methods of soybean plant inoculation the most suitable is the laboratory method in which discs of the fungal culture were placed on injured seedlings, this giving the quickest and most precise results. Other methods are more time consuming and their results are difficult to compare because of difficulties in repeatability of the results. This may have also been caused by partial lack of precision in the methods used. In spite of application of methods varying in precision, none of the isolates exhibited a high pathogenicity for soybean and other plants, this being characteristic for the fungus Phoma exigua var. exigua, as reported by B o e r e m a and $\mathrm{H}$ ö w e 1 e r $\langle 1967\rangle$ in reference to other plants tested by them.

\section{CONCLUSIONS}

1. Among the methods of plant inoclation most suitable for estimation of the pathogenicity of the fungus $P$. exigua var. exigua is considered the laboratory method of inoculation with fungus culture discs, and among the methods of seed inoculation, soaking of seeds in a suspension of fungal conidia.

2. For successful inoculation of soybean and other plants the injury of inoculated organs was decisive. The tested fungus did not infect intact plants, this being evidence of its weak pathogenicity towards soybean and other plants.

3. The tested fungus isolated from soybean is not a specific pathogen of this plant since it infected injured plants not only of soybean but of other species.

4. The different time of exposure of the inoculated plants to conditions of 100 per cent relative air humidity had no influence on the incidence rate in intact and also injured plants.

5. Each of the three methods of seed inoculation depressed the germination capacity of the seeds and the health condition of the seedlings.

6. On the basis of the morphological features of the fungus and its pathogenicity towards soybean and other tested plants it was established that it is the species Phoma exigua Desm. var exigua.

7. Various isolates of this fungus from soybean and the isolate from chicory behaved similarly as weak pathogens towards various infected plants.

\section{REFERENCES}

A b r a m o v I. N., 1931. Gribnye bolezni soevykh bobov na Dal'nem Vostoke. Bolezni i vrediteli soevykh bobov na Dal'nem Vostoke. Vladivostok: 3-84.

B o e r e m a G. H., H ö w e 1 e r L. H., 1967. Phoma exigua Desm. and its varieties. Persoonia 5: 15-28.

B o e r e m a G. H., C r üg e r G., G e r 1 a g h M., N i r e n be r g H., 1981. Phoma exigua var. diversispora and related fungi on Phaseolus beans. Journal of Plant Diseases and Protection 88: $597-607$. 
B ondarceva-M on teverde V. N., Va si l'e vski i N. I., 1940. K biologii i morfologii nektorykh vidov Ascochyta na bobovykh. Sporovye Rasteniya 4: 345-376.

C r o s s a n D. F., 1953. Comparative studies on species of Ascochyta from okra, bean and cotton in North Carolina. Phytopathology 43: 469.

D u n l e a v y J. M., 1958, Studies of a seedling blight of soybeans and the etiology of the causal fungus, Diaporthe phaseolorum var. caulivora. Proc. Iowa Acad. Sci. 65: 131-145.

F r a n d s e n N. O., 1953. Ascochyta sojaecola auf Sojabohne in Deutschland. Phytopath. Z. 20: 375-382.

M a r c i n k o w s k a J., 1977. Septorioza pomidora. I. Rozwój choroby w warunkach szklarniowych i polowych. Acta Agrobot. 30: 341-358.

Marcinkowska J., Toma la-Bednarek J. W., Schollenberge r M., 1982. Soybean diseases in Poland. Acta Agrobot. 35: 213-224.

M a r c i n k o w s k a J., 1983. Charakterystyka izolatów grzyba Phoma exigua. Acta Mycol. (in press).

M e 1 n i k W. A., 1977. Opredelitel' gribov roda Ascochyta Lib.. Izdatelstvo „Nauka”, Leningrad: 127-128.

O n d r e j M., 1976. K vỳskytu a ŝkodlivosti polyfágni houby Phoma exigua Desm. Ochr. Rostl. 12: 239-242.

S a w a d a K., 1959. Descriptive catalogue of Taiwan 〈Formosan〉 fungi. Part XI. Natl. Taiwan Univ. 〈Taipei〉 Coll. Agr. Spec. Bull. 8: 268.

T ò t h O., K ö v i c s G., 1978. Az Ascochyta sojaecola Abramov szoja kórokozó Magyarországi megjelenése. Növényvédelem 14: 299-304.

\section{Metody oceny patogeniczności grzyba Phoma exigua var. exigua}

\section{Streszczenie}

W latach 1977-1981 wyizolowano z liści, pędów, szyjek korzeniowych i nasion soi uprawnej w różnych okolicach Polski 33 izolaty grzyba Phoma exigua. Żaden z izolatów nie wywołał objawów chorobowych po inokulacji nieuszkodzonych roślin soi i roślin innych gatunków. Dopiero po inokulacji roślin uszkodzonych w różny sposób, obserwowano ich porażenie. Porażeniu uległy zarówno soja jak i inne rośliny, co świadczy o polifagicznym charakterze grzyba. Na podstawie tych czynników zidentyfikowano grzyb jako Phoma exigua var. exigua.

Po zastosowaniu siedmiu metod oceny patogeniczności uzyskano różną liczbę chorych roślin. Gdy inokulowano nasiona zazwyczaj mało siewek wykazywało objawy zgorzeli. Najefektywniejszą z trzech metod zakażania nasion okazała się metoda moczenia nasion w zawiesinie konidiów grzyba. Spośród metod inokulacji siewek oraz roślin starszych soi i innych gatunków za najlepszą uznano metodę wykładania krążków kultur na hypokotyl w warunkach laboratoryjnych. Wszystkie pozostałe metody, oprócz różnego stopnia precyzji, są bardziej pracochłonne, ponieważ wymagaja uprawiania roślin w doniczkach i doświadczeń wykonanych w szklarni. 